TITLE:

\title{
A Hydronium Solvate lonic Liquid: Facile Synthesis of Air-Stable Ionic Liquid with Strong Bronsted Acidity
}

\section{$\operatorname{AUTHOR}(\mathrm{S}):$}

Kitada, Atsushi; Takeoka, Shun; Kintsu, Kohei; Fukami, Kazuhiro; Saimura, Masayuki; Nagata, Takashi; Katahira, Masato; Murase, Kuniaki

\section{CITATION:}

Kitada, Atsushi ...[et al]. A Hydronium Solvate Ionic Liquid: Facile Synthesis of Air-Stable Ionic Liquid with Strong Bronsted Acidity. Journal of the Electrochemical Society 2018, 165(3): H121-H127

\section{ISSUE DATE:}

2018-02-22

URL:

http://hdl.handle.net/2433/240665

\section{RIGHT:}

(c) The Author(s) 2018. Published by ECS. This is an open access article distributed under the terms of the Creative Commons Attribution 4.0 License (CC BY, http://creativecommons.org/licenses/by/4.0/), which permits unrestricted reuse of the work in any medium, provided the original work is properly cited. 


\title{
A Hydronium Solvate Ionic Liquid: Facile Synthesis of Air-Stable Ionic Liquid with Strong Brønsted Acidity
}

EGS

\author{
Atsushi Kitada, ${ }^{1, \mathrm{r}}$ Shun Takeoka, ${ }^{1}$ Kohei Kintsu, ${ }^{1}$ Kazuhiro Fukami, ${ }^{1, *}$ \\ Masayuki Saimura, ${ }^{2}$ Takashi Nagata, ${ }^{2}$ Masato Katahira, ${ }^{2}$ and Kuniaki Murase ${ }^{1, *}$ \\ ${ }^{1}$ Department of Materials Science and Engineering, Kyoto University, Yoshida-honmachi, Sakyo, Kyoto 606-8501, \\ Japan \\ ${ }^{2}$ Institute of Advanced Energy, Gokasho, Uji, Kyoto 611-0011, Japan
}

\begin{abstract}
A new kind of ionic liquid (IL) with strong Brønsted acidity, i.e., a hydronium $\left(\mathrm{H}_{3} \mathrm{O}^{+}\right)$solvate ionic liquid, is reported. The IL can be described as $\left[\mathrm{H}_{3} \mathrm{O}^{+} \cdot 18 \mathrm{C} 6\right] \mathrm{Tf}_{2} \mathrm{~N}$, where water exists as the $\mathrm{H}_{3} \mathrm{O}^{+}$ion solvated by 18 -crown-6-ether (18C6), of which the counter anion is bis(trifluoromethylsulfonyl)amide $\left(\mathrm{Tf}_{2} \mathrm{~N}^{-} ; \mathrm{Tf}=\mathrm{CF}_{3} \mathrm{SO}_{2}\right)$. The hydrophobic $\mathrm{Tf}_{2} \mathrm{~N}^{-}$anion makes $\left[\mathrm{H}_{3} \mathrm{O}^{+} \cdot 18 \mathrm{C} 6\right] \mathrm{Tf}_{2} \mathrm{~N}$ stable in air. The Hammett acidity function $\left(H_{0}=-4.4\right)$ of molten $\left[\mathrm{H}_{3} \mathrm{O}^{+} \cdot 18 \mathrm{C} 6\right] \mathrm{Tf}_{2} \mathrm{~N}$, evaluated using the indicator method, is a new record for ILs and indicates strong aciditiy. The findings regarding this proton-condensed solvate IL are of fundamental interest, and will help in the design of media for new acid-base reactions.

(c) The Author(s) 2018. Published by ECS. This is an open access article distributed under the terms of the Creative Commons Attribution 4.0 License (CC BY, http://creativecommons.org/licenses/by/4.0/), which permits unrestricted reuse of the work in any medium, provided the original work is properly cited. [DOI: 10.1149/2.0481803jes]

(cc) BY
\end{abstract}

Manuscript submitted December 11, 2017; revised manuscript received February 12, 2018. Published February 22, 2018. This was Paper 3475 presented at the Honolulu, Hawaii, Meeting of the Society, October 2-7, 2016.

When two or more kinds of substances are mixed, the properties of the mixture can differ from those of the pure substances. Depending on the interactions between the components, some components undergo ionization, e.g. dissociation, protonation, solvation and complexation, due to the neutralization of Brønsted or Lewis acids and bases. Sometimes, the acid-base mixtures can be categorized as ionic liquids (ILs) with melting points below $100^{\circ} \mathrm{C}$, which consist only of cations and anions. ILs are regarded as "the third liquid" and some ILs have fascinating physicochemical properties, such as low volatility, low flammability, high chemical, and thermal stability. Furthermore, ILs have received growing interest due to their various uses as media in chemical, biochemical, and/or electrochemical systems. ${ }^{1-6}$

Common anions of ILs such as $\mathrm{BF}_{4}^{-}, \mathrm{PF}_{6}{ }^{-}$, and $\mathrm{AlCl}_{4}{ }^{-}$are produced by neutralization, i.e. the adducts of a Lewis acid $\left(\mathrm{BF}_{3}, \mathrm{PF}_{5}\right.$, or $\left.\mathrm{AlCl}_{3}\right)$ and a Lewis base $\left(\mathrm{F}^{-}\right.$or $\left.\mathrm{Cl}^{-}\right)$. Examples of ILs prepared through neutralization include solvate ILs. ${ }^{7-13}$ Solvate ILs often consist of equimolar molten mixtures of polyethers (linear or cyclic ones, i.e. glymes or crown ethers) and certain metal salts, where the Lewis acidic metal cations are solvated by equimolar amounts of Lewis basic glymes to give complex cations. Besides, neutralization of Brønsted acids and bases produces so-called protic ILs, which are preferred as acid-catalyzed reaction media due to the presence of an acidic proton. ${ }^{3-6}$ Since proton transfer is a common chemical transformation, Brønsted acidic ILs receive research attention especially for acid catalysts, fuel cells, biomass processing, polymerization, $\mathrm{CO}_{2}$ fixation, etc. ${ }^{6,14-19}$ The design of stronger Brønsted acidic ILs and evaluation of the acidity in ILs are important for exploring their possible applications as media for acid-base reactions.

Although protons are often written as $\mathrm{H}^{+}, \mathrm{H}^{+}$cannot exist as a bare ion in liquids. ${ }^{20}$ In aqueous solutions, " $\mathrm{H}^{+}$aq" exists as $\mathrm{H}^{+}\left(\mathrm{H}_{2} \mathrm{O}\right)_{n}$ with $n=1,2,3, \ldots$ i.e. $\mathrm{H}_{3} \mathrm{O}^{+}, \mathrm{H}_{5} \mathrm{O}_{2}{ }^{+}, \mathrm{H}_{7} \mathrm{O}_{3}{ }^{+}$, etc. The simplest form is $\mathrm{H}_{3} \mathrm{O}^{+}$, commonly called a hydronium ion. In a monohydrate acid $\left(\mathrm{H} A \cdot \mathrm{H}_{2} \mathrm{O}\right)$, the protons are not bonded to the anion atoms. Protons generally exist as hydronium ions to form $\mathrm{H}_{3} \mathrm{O}^{+} \cdot A^{-}$, where $\mathrm{HA}=\mathrm{HNO}_{3}, \mathrm{H}_{2} \mathrm{SO}_{4}, \mathrm{HClO}_{4}, \mathrm{HTfO}\left(\mathrm{Tf}=\mathrm{CF}_{3} \mathrm{SO}_{2}\right)$, etc. ${ }^{21-24}$ However, there is an exception. In solid, anhydrous $\mathrm{HTf}_{2} \mathrm{~N}$, the proton is bonded to the anion nitrogen and two oxygens of a neighboring $\mathrm{HTf}_{2} \mathrm{~N}$ molecule. ${ }^{25}$ Likewise, in the case of monohydrate, the imide superacid $\mathrm{HTf}_{2} \mathrm{~N}$ remains associated and does not protonate water, as suggested experimentally and theoretically. In the infrared measurements for an $\mathrm{H}_{2} \mathrm{O}$ and $\mathrm{HTf}_{2} \mathrm{~N}$ mixture in $\mathrm{CCl}_{4}$, strong Fermi resonance for $\mathrm{N}-\mathrm{H}$ vibrations serves as evidence that $\mathrm{HTf}_{2} \mathrm{~N}$ remains intact, and from the ab initio calculations, spontaneous proton dissociation was not observed for the $\mathrm{HTf}_{2} \mathrm{~N}$ molecule with the addition of one $\mathrm{H}_{2} \mathrm{O}$ molecule. ${ }^{26,27}$ Notably, in a non-fluorinated analogue i.e. $\left(\mathrm{CH}_{3} \mathrm{SO}_{2}\right)_{2} \mathrm{NH} \cdot \mathrm{H}_{2} \mathrm{O}$ imide monohydrate, the proton remains bonded to the anion nitrogen, ${ }^{28}$ although the network may change at elevated temperatures to form $\mathrm{H}_{3} \mathrm{O}^{+}$trapped in an anionic cage, as reported for $\mathrm{HClO}_{4} \cdot \mathrm{H}_{2} \mathrm{O}$. ${ }^{24}$ Protonation of water using equimolar $\mathrm{HTf}_{2} \mathrm{~N}$ could occur only if $\mathrm{H}_{3} \mathrm{O}^{+}$were solvated by ligands, thereby synthesizing a new series of ionic materials, i.e. hydronium solvate ILs, the active protons of which would show strong acidities in the form of (solvate) IL.

A plausible ligand for complexation of $\mathrm{H}_{3} \mathrm{O}^{+}$is a crown ether, 18-crown-6-ether (18C6). 18C6 is a good hydrogen-bonding acceptor that binds $\mathrm{H}_{3} \mathrm{O}^{+}$cation selectively due to its cavity size resulting in the formation of an $\left[\mathrm{H}_{3} \mathrm{O}^{+} \cdot 18 \mathrm{C} 6\right]$ complex cation. ${ }^{29-33}$ In this paper, we report for the first time that $\mathrm{H}_{3} \mathrm{O}^{+}$can be stabilized by the addition of $18 \mathrm{C} 6$ to $\mathrm{HTf}_{2} \mathrm{~N} \cdot \mathrm{H}_{2} \mathrm{O}$, forming $\left[\mathrm{H}_{3} \mathrm{O}^{+} \cdot 18 \mathrm{C} 6\right] \mathrm{Tf}_{2} \mathrm{~N}$ (see Fig. 1a). The successful synthesis of $\left[\mathrm{H}_{3} \mathrm{O}^{+} \cdot 18 \mathrm{C} 6\right] \mathrm{Tf}_{2} \mathrm{~N}$ clarified
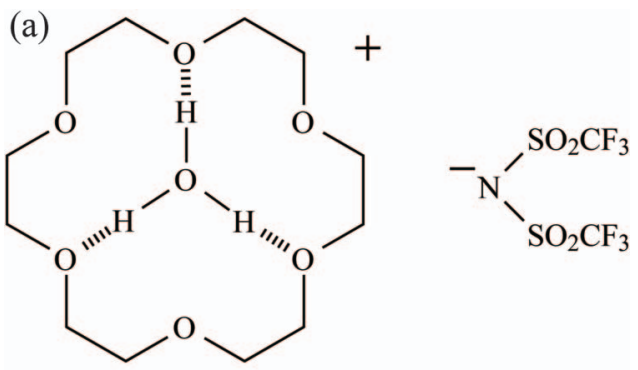

(b)
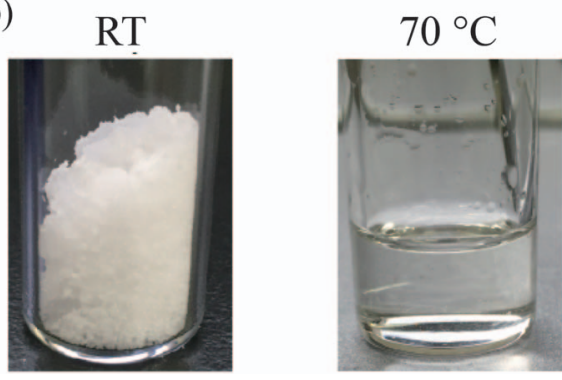

Figure 1. (a) Schematic structure of $\left[\mathrm{H}_{3} \mathrm{O}^{+} \cdot 18 \mathrm{C} 6\right] \mathrm{Tf} f_{2} \mathrm{~N}$ and (b) Photographs of $\left[\mathrm{H}_{3} \mathrm{O}^{+} \cdot 18 \mathrm{C} 6\right] \mathrm{Tf}_{2} \mathrm{~N}$ at RT and $70^{\circ} \mathrm{C}$. 
its unusually low melting point of $68-70^{\circ} \mathrm{C}$, compared with the known $\left[\mathrm{H}_{3} \mathrm{O}^{+}\right.$. 18C6] complexes with common anions of ILs, such as $\mathrm{ClO}_{4}{ }^{-}$, $\mathrm{SbF}_{6}{ }^{-}, \mathrm{PF}_{6}{ }^{-}, \mathrm{TfO}^{-}, \mathrm{BF}_{4}^{-}, \mathrm{FeCl}_{4}{ }^{-}\left(110-170^{\circ} \mathrm{C}\right) .^{30-33}$ Moreover, the $\mathrm{Tf}_{2} \mathrm{~N}^{-}$anion is known for its strong hydrophobicity and high chemical stability. ${ }^{34,35}$ These characteristic features allowed the facile synthesis of air-stable or non-hygroscopic $\left[\mathrm{H}_{3} \mathrm{O}^{+} \cdot 18 \mathrm{C} 6\right] \mathrm{Tf}_{2} \mathrm{~N}$ just by vacuum drying of an equimolar $18 \mathrm{C} 6-\mathrm{HTf}_{2} \mathrm{~N}$ aqueous solution. We confirm that the hydronium complex $\left[\mathrm{H}_{3} \mathrm{O}^{+} \cdot 18 \mathrm{C} 6\right] \mathrm{Tf}_{2} \mathrm{~N}$ satisfies the criteria of a solvate IL, ${ }^{7}$ containing a negligible amount of neutral molecules. We also reveal that the hydronium solvate IL is highly acidic (Hammett acidity function $H_{0}=-4.4$ ), marking a new record of $H_{0}$ among acidic ILs.

\section{Experimental}

Materials for $\left[\mathrm{H}_{3} \mathrm{O}^{+} \cdot \mathbf{1 8 C 6}\right] \mathrm{Tf}_{2} \mathrm{~N} .-18$-crown-6 (18C6; Kanto Chemical, $99 \%$ purity) and bis(trifluoromethylsulfonyl)imide ( $\mathrm{HTf}_{2} \mathrm{~N}$; Aldrich, $\geq 95 \%$ purity) were used without further purification. Deionized water was prepared using a Merck Milli-Q Reference A system. Note: Wilson et al. have discussed the naming of $\mathrm{HTf}_{2} \mathrm{~N}$ and $\mathrm{Tf}_{2} \mathrm{~N}^{-}$anion. ${ }^{36} \mathrm{HTf}_{2} \mathrm{~N}$ was originally named as bis((trifluoromethyl)sulfonyl)imide. ${ }^{37}$ According to IUPAC nomenclature, $\operatorname{HTf}_{2} \mathrm{~N}$ is a "sulfonamide", named as 1,1,1-trifluoro- $N$ [(trifluoromethyl)sulfonyl]-methanesulfonamide. ${ }^{38}$ Besides, $\mathrm{HTf}_{2} \mathrm{~N}$ can be viewed as bis(trifluoromethanesulfonyl)amine, ${ }^{25}$ but this name ignores one of the accepted principles of nomenclature. However, its conjugate base anion i.e. $\mathrm{Tf}_{2} \mathrm{~N}^{-}$anion is clearly an amide, bis(trifluoromethylsulfonyl)amide or bis(trifluoromethanesulfonyl)amide, commonly abbreviated to TFSA. In some literature, the anion is referred to as an "imide" with the abbreviation TFSI; however, the now-accepted naming is "amide".

Synthesis of $\left[\mathrm{H}_{3} \mathrm{O}^{+} \cdot \mathbf{1 8 C 6}\right] \mathrm{Tf}_{2} \mathrm{~N} .-18 \mathrm{C} 6(5 \mathrm{mmol})$ and $\mathrm{HTf}_{2} \mathrm{~N}$ $(5 \mathrm{mmol})$ in $5 \mathrm{~mL}$ of water were stirred at $500 \mathrm{rpm}$ and heated at $50^{\circ} \mathrm{C}$ for 1 day in air, followed by vacuum-drying at $50^{\circ} \mathrm{C}$ for 3 days. A white, non-hygroscopic (air-stable) solid was obtained at room temperature (RT), which melts at $\sim 70^{\circ} \mathrm{C}$, forming a colorless liquid (see Fig. 1b).

Characterization as a solvate IL.-For Raman measurements at RT an integrated Raman system (B\&W Tek, innoRam 785), consisting of a semiconductor laser light source $(785 \mathrm{~nm})$, an axial transmissive spectrograph, a holographic probe head, and a CCD detector, was used. To lessen the interference by fluorescence, the sample was mixed with active carbon in acetone overnight, then filtered and finally vacuum-dried to obtain a purified sample. The purity was evaluated by chemical analysis. The spectral acquisition time, i.e., exposure time of $\mathrm{CCD}$ and the number of exposures was varied for each sample to improve the signal-to-noise ratio of each spectrum. Infrared (IR) measurements were conducted using a JASCO FT/IR-460 plus system. For the IR measurement, Nujol and hexachlorobutadiene mulls painted on a barium fluoride window were used at RT. Nuclear magnetic resonance (NMR) spectra were obtained using a JNM-ECA600 FT NMR spectrometer (JEOL Ltd.). ${ }^{1} \mathrm{H}$ NMR, ${ }^{13} \mathrm{C}$ NMR, and ${ }^{19} \mathrm{~F}$ NMR spectra were obtained at $75^{\circ} \mathrm{C}$. The use of a double NMR tube, purchased from Shigemi Corp. (catalog No. SC-002), prevented mixing of the sample and an external standard: traces of dimethyl sulfoxide- $\mathrm{d}_{6}$ (Aldrich, 99.9 atom $\% \mathrm{D}$ ) were placed in the outer tube $(5.2 \mathrm{~mm} \phi)$, and $\left[\mathrm{H}_{3} \mathrm{O}^{+} \cdot 18 \mathrm{C} 6\right] \mathrm{Tf}_{2} \mathrm{~N}$ in the internal tube $(5.0 \mathrm{~mm} \phi)$. The melting point of the complex was evaluated by means of a differential scanning calorimeter (DSC; Shimadzu, DSC-60) with a sweeping rate of $5^{\circ} \mathrm{C} \mathrm{min}{ }^{-1}$ by heating from room temperature up to $80^{\circ} \mathrm{C}$ and then cooling down to $40^{\circ} \mathrm{C}$. Thermal gravimetric analysis (TGA) measurements were performed using a Netzsch STA 2500 instrument in a helium atmosphere at $5 \mathrm{~K} \mathrm{~min}^{-1}$. The $4.9-\mathrm{mg}$ sample was placed on an $\mathrm{Al}$ pan and $\mathrm{Al}_{2} \mathrm{O}_{3}$ was used as a standard.

Viscosity and conductivity.-Conductivity measurements were performed between $75^{\circ} \mathrm{C}$ and $95^{\circ} \mathrm{C}$ by the AC impedance method using a Radiometer Analytical CDM230. Viscosity measurements were conducted using Sekonic VM-10A and VM-1G calibrated using a standard solution (Nippon Grease Co., Ltd.). The density of the sample was calculated to be $1.32 \mathrm{~g} \mathrm{~cm}^{-3}$ at $70^{\circ} \mathrm{C}$ using the measured values of weight and volume.

Electrochemical measurements.-Linear sweep voltammetry (LSV) was conducted in air for $\left[\mathrm{H}_{3} \mathrm{O}^{+} \cdot 18 \mathrm{C} 6\right] \mathrm{Tf}_{2} \mathrm{~N}$ at $90^{\circ} \mathrm{C}$ without agitation using a potentiostat (HSV-110, Hokuto Denko). A Pt disk electrode ( $3 \mathrm{~mm} \phi$, PT-6355, EC Frontier) and a glassy carbon electrode (Toyo Tanso) were used as the working electrode (WE) and counter electrode (CE), respectively. It is reported that a Sn electrode shows stable potential and can be used as the reference electrode (RE) ${ }^{39}$ Thus, as the RE a Sn rod was immersed in $50 \mathrm{mmol} \mathrm{dm}^{-3} \mathrm{Sn}\left(\mathrm{Tf}_{2} \mathrm{~N}\right)_{2}$ - made from $\mathrm{SnO}$ and $\mathrm{HTf}_{2} \mathrm{~N}^{39}$ - in 1-ethyl3-methylimidazolium bis(trifluoromethylsulfonyl)amide $\left(\right.$ EMITf $_{2} \mathrm{~N}$; Kanto Chemical, 99.9\% purity), separated from the main electrolyte by porous Vycor glass. Before the measurements, the WE and CE were washed with acetone and the RE was washed with $1 \mathrm{~mol} \mathrm{dm}^{-3}$ $\mathrm{HCl}$ aqueous solution.

Determination of hammett acidity function.-The Brønsted acidity was evaluated from the determination of the Hammett acidity functions, by an indicator method via UV-visible spectroscopy. ${ }^{40-42}$ The Hammett acidity function $\left(H_{0}\right)$ is defined as

$$
H_{0}=\mathrm{p} K(I)_{\mathrm{aq}}+\log \left([I]_{\mathrm{s}} /\left[I \mathrm{H}^{+}\right]_{\mathrm{s}}\right)
$$

where $\mathrm{p} K(I)_{\mathrm{aq}}$ is the $\mathrm{p} K_{\mathrm{a}}$ value of the spectroscopic indicator referred to in aqueous solution. $[I]_{\mathrm{s}}$ indicates the molar concentration of the unprotonated $(I)$ form of the indicator in the solvent; $\left[I \mathrm{H}^{+}\right]_{\mathrm{s}}$ represents the molar concentration of the protonated $\left(\mathrm{IH}^{+}\right)$forms. 2,4dinitroaniline (Tokyo Chemical Industry Co., Ltd., $\geq 99.0 \%$ purity, $\left.\mathrm{p} K_{\mathrm{a}}(I)_{\mathrm{aq}}=-4.53\right)$ was used as an indicator. $H_{0}$ of $\left[\mathrm{H}_{3} \mathrm{O}^{+} \cdot 18 \mathrm{C} 6\right] \mathrm{Tf}_{2} \mathrm{~N}$ at $75^{\circ} \mathrm{C}$ was measured by a UV-visible spectrometer (U-3500, Hitachi). 2,4-dinitroaniline $\left(2.74 \times 10^{-4} \mathrm{~mol} \mathrm{dm}^{-3}\right)$ was added and stirred into $\left[\mathrm{H}_{3} \mathrm{O}^{+} \cdot 18 \mathrm{C} 6\right] \mathrm{Tf}_{2} \mathrm{~N}$ at $75^{\circ} \mathrm{C}$ to form a solution. The reference absorbance was obtained using $2.74 \times 10^{-4} \mathrm{~mol} \mathrm{dm}^{-3}$ of 2,4dinitroaniline in anhydrous ethanol (Wako Chemical).

To compare the acidity between $\left[\mathrm{H}_{3} \mathrm{O}^{+} \cdot 18 \mathrm{C} 6\right] \mathrm{Tf}_{2} \mathrm{~N}$ and $\mathrm{HTf}_{2} \mathrm{~N}$, $\left[\mathrm{H}_{3} \mathrm{O}^{+} \cdot 18 \mathrm{C} 6\right] \mathrm{Tf}_{2} \mathrm{~N}$ or $\mathrm{HTf}_{2} \mathrm{~N}$ was dissolved in a common IL, and $H_{0}$ was measured at RT. Note that since the use of an IL as a solvent will certainly affect the results, the acidity depends on the selected solvent. In this work, a common IL, $\operatorname{EMITf}_{2} \mathrm{~N}$, was chosen as the solvent. $2.0 \times 10^{-4} \mathrm{~mol} \mathrm{dm}^{-3}$ of 2,4-dinitroaniline in EMITf $_{2} \mathrm{~N}$ was stirred for 1 day at $110^{\circ} \mathrm{C}$ in an Ar-filled glove box to remove water. Then $\left[\mathrm{H}_{3} \mathrm{O}^{+} \cdot 18 \mathrm{C} 6\right] \mathrm{Tf}_{2} \mathrm{~N}$ or $\mathrm{HTf}_{2} \mathrm{~N}$ was added and stirred in the indicator solution for $10 \mathrm{~min}$ at RT in the glove box. These EMITf ${ }_{2} \mathrm{~N}$ solutions were placed into screw-capped cells in the glove box, and transferred into a UV-visible spectrometer (U-3500, Hitachi) for measurements at RT. Concentrations of $\left[\mathrm{H}_{3} \mathrm{O}^{+} \cdot 18 \mathrm{C} 6\right] \mathrm{Tf}_{2} \mathrm{~N}$ ranged from 50 to $2000 \mathrm{mmol} \mathrm{dm}^{-3}$, and those of $\mathrm{HTf}_{2} \mathrm{~N}$ from 50 to $1000 \mathrm{mmol}$ $\mathrm{dm}^{-3}$.

\section{Results and Discussion}

Facile synthesis of $\left[\mathrm{H}_{3} \mathrm{O}^{+} \cdot 18 \mathrm{C6}\right] \mathrm{Tf}_{2} \mathrm{~N}$.- The strong hydrophobicity and high chemical stability of the $\mathrm{Tf}_{2} \mathrm{~N}^{-}$anion allowed the facile synthesis of $\left[\mathrm{H}_{3} \mathrm{O}^{+} \cdot 18 \mathrm{C} 6\right] \mathrm{Tf}_{2} \mathrm{~N}$. Here, water acts bifunctionally, i.e. both as a reactant and as the reaction solvent, from which a solid sample of $\left[\mathrm{H}_{3} \mathrm{O}^{+} \cdot 18 \mathrm{C} 6\right] \mathrm{Tf}_{2} \mathrm{~N}$ was obtained successfully via vacuum drying at $50^{\circ} \mathrm{C}$. In contrast, the known $\left[\mathrm{H}_{3} \mathrm{O}^{+} \cdot 18 \mathrm{C} 6\right]$ complexes have been synthesized using an organic solvent (e.g. tetrahydrofuran, benzene, $\mathrm{CH}_{2} \mathrm{Cl}_{2}$ ), into which only a stoichiometric amount of $\mathrm{H}_{2} \mathrm{O}$ was added as a reactant with $18 \mathrm{C} 6$ and an acid. ${ }^{30-33}$ We believe that the reason why an organic solvent was used is that some of the anions (e.g. $\mathrm{BF}_{4}{ }^{-}$and $\mathrm{FeCl}_{4}{ }^{-}$) are hydrophilic and it is difficult to obtain the pure $\left[\mathrm{H}_{3} \mathrm{O}^{+}\right.$. 18C6] complexes. Another reason is that an excess amount of water can cause hydrolysis or decomposition of anions $\left(\mathrm{SbF}_{6}{ }^{-}\right.$, $\mathrm{PF}_{6}{ }^{-}, \mathrm{BF}_{4}^{-}, \mathrm{FeCl}_{4}{ }^{-}$), which creates impurities such as $\mathrm{HF}$ or $\mathrm{HCl}$. For 
Table I. Result of chemical analysis for $\left[\mathrm{H}_{3} \mathrm{O}^{+} \cdot 18 \mathrm{C} 6\right] \mathrm{Tf}_{2} \mathrm{~N}$

\begin{tabular}{cccccc} 
element & $\mathrm{H}[\mathrm{wt} \%]$ & $\mathrm{C}[\mathrm{wt} \%]$ & $\mathrm{N}[\mathrm{wt} \%]$ & $\mathrm{F}[\mathrm{wt} \%]$ & $\mathrm{S}[\mathrm{wt} \%]$ \\
\hline experimental & 4.90 & 29.97 & 2.40 & 20.07 & 11.35 \\
calculated & 4.83 & 29.84 & 2.49 & 20.23 & 11.38
\end{tabular}

example, it is reported that the $\mathrm{PF}_{6}{ }^{-}$anion can be decomposed by moisture and result in $\mathrm{HF}, \mathrm{POF}_{3}$, etc. ${ }^{43}$ In contrast, $\mathrm{Tf}_{2} \mathrm{~N}^{-}$salts are known to be dehydrated without significant decomposition.

Classification of $\left[\mathrm{H}_{3} \mathrm{O}^{+} \cdot 18 \mathrm{C6}\right] \mathrm{Tf}_{2} \mathrm{~N}$ into a solvate IL.-According to Mandai et al., ${ }^{7}$ solvate ILs should satisfy all the following criteria(1)-(5):

(1) Form a solvate compound between an ion and a ligand(s) in a certain stoichiometric ratio.

(2) Consist entirely of complex ions (solvates) and their counter ions in the molten state.

(3) Show no physicochemical properties based on both pure ligands and precursor salts under usage conditions.

(4) Have a melting point below $100^{\circ} \mathrm{C}$, which satisfies the criterion for typical ILs.

(5) Have a negligible vapor pressure under typical application conditions.

Firstly, chemical analysis data for $\mathrm{H}, \mathrm{C}, \mathrm{N}, \mathrm{F}$, and $\mathrm{S}$ were consistent with the suggested formulation $\left[\mathrm{H}_{3} \mathrm{O}^{+} \cdot 18 \mathrm{C} 6\right] \mathrm{Tf}_{2} \mathrm{~N}$ (within \pm 0.2 wt $\%$ of the calculated value; see Table I). The $\mathrm{H}_{2} \mathrm{O}$ content of the complex was $3.29 \mathrm{wt} \%$ analyzed by Karl-Fischer coulometric titration, in good agreement with the calculated value $(3.20 \mathrm{wt} \%)$. In addition, the $\mathrm{H}_{2} \mathrm{O}$ content of the sample, kept in a screw-capped vial (not a septum) in air at RT for 2 weeks, did not vary within the experimental limit. This proved the air-stable nature of $\left[\mathrm{H}_{3} \mathrm{O}^{+} \cdot 18 \mathrm{C} 6\right] \mathrm{Tf}_{2} \mathrm{~N}$, i.e. water absorption is very slow. Consequently, these quantitative analysis results strongly support that the complex was $18 \mathrm{C} 6: \mathrm{H}_{2} \mathrm{O}: \mathrm{HTf}_{2} \mathrm{~N}=1: 1: 1$ by mole, satisfying criterion (1).

Secondly, the Raman results shown in Fig. 2 satisfy criteria (2) and (3). This point is also supported by the IR results shown in Fig. 3. The Raman spectrum for molten $\left[\mathrm{H}_{3} \mathrm{O}^{+} \cdot 18 \mathrm{C} 6\right] \mathrm{Tf}_{2} \mathrm{~N}$ clearly illustrates that any bands attributable to free 18C6 ligand molecules are absent. The appearance of the Raman peak centered at $873 \mathrm{~cm}^{-1}$, the so-called breathing mode, means a change in the COC stretching and $\mathrm{CH}_{2}$ rocking modes of $18 \mathrm{C} 6$ due to the complex formation, as in the case of alkali metal ether complexes. ${ }^{7-13}$ In the IR spectra, the COC stretching absorption for pure $18 \mathrm{C} 6$ is seen as a broad

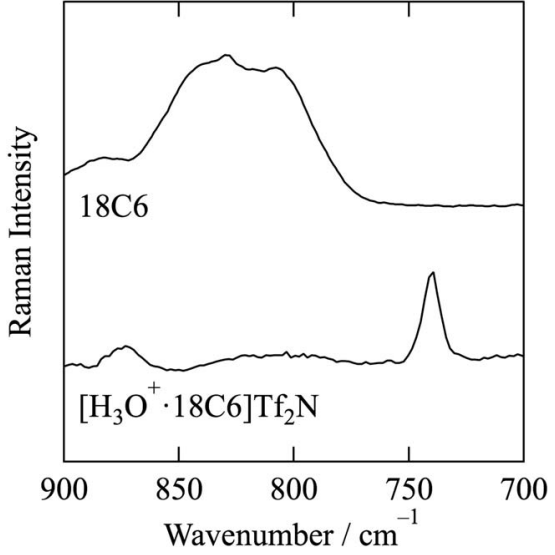

Figure 2. Raman spectra between $700 \mathrm{~cm}^{-1}$ and $900 \mathrm{~cm}^{-1}$ of pure $18 \mathrm{C} 6$ $\left(50^{\circ} \mathrm{C}\right)^{13}$ and $\left[\mathrm{H}_{3} \mathrm{O}^{+} \cdot 18 \mathrm{C} 6\right] \mathrm{Tf}_{2} \mathrm{~N}\left(75^{\circ} \mathrm{C}\right)$, both in the molten state.

band at $1125 \mathrm{~cm}^{-1}$, which disappeared and split into sharp bands at $1138 \mathrm{~cm}^{-1}$ and $1091 \mathrm{~cm}^{-1}$ because of $\left[\mathrm{H}_{3} \mathrm{O}^{+} \cdot 18 \mathrm{C} 6\right]$ formation (see Fig. 3a). ${ }^{30}$ The presence of $\mathrm{H}_{3} \mathrm{O}^{+}$with $18 \mathrm{C} 6$ is readily established from the characteristic bands in the IR spectra i.e. $v_{1}-v_{4}$ (see Fig. $3 \mathrm{~b}) .^{30,31}$ The $\nu_{1}$ and $\nu_{3}$ stretching modes give a very broad band centered at $2920 \mathrm{~cm}^{-1}$, which overlaps the sharper maximum at $2880 \mathrm{~cm}^{-1}$ arising from the $\mathrm{C}-\mathrm{H}$ stretching motions of $18 \mathrm{C} 6$. The $\nu_{4}$ band at 1650 $\mathrm{cm}^{-1}$ is attributable to the bending mode, and that at $2200 \mathrm{~cm}^{-1}$ is the first harmonic of $\nu_{2}$, i.e. the symmetric bending mode. The $\nu_{2}$ band at $1100 \mathrm{~cm}^{-1}$ is not clearly observed, where a strong band from $18 \mathrm{C} 6$ overlaps. Consequently, the IR spectra clearly display the presence of $\mathrm{H}_{3} \mathrm{O}^{+}$. Therefore, it is proved that all $18 \mathrm{C} 6$ ligands coordinate to hydronium cations to form $\left[\mathrm{H}_{3} \mathrm{O}^{+} \cdot 18 \mathrm{C} 6\right]$. The anionic band appears at $739 \mathrm{~cm}^{-1}$ without shoulder peaks. Although the resolution is low, its full width at half maximum (FWHM) is comparable to that of the anionic band for "free" $\mathrm{Tf}_{2} \mathrm{~N}^{-}$in our previous report. ${ }^{44}$ This indicates that the $\mathrm{Tf}_{2} \mathrm{~N}^{-}$anions are "free" and not forming complex anions such as $\left[\mathrm{H}\left(\mathrm{Tf}_{2} \mathrm{~N}\right)_{2}\right]^{-} .45$

Thirdly, DSC measurements revealed a single endothermic peak and a corresponding exothermic peak (see Fig. 4). The ratio of integrated peak areas for the melting and those for subsequent crystallization was close to unity. The melting point was $68-70^{\circ} \mathrm{C}$, satisfying criterion (4). Since no additional peaks were seen around the melting points of pure $18 \mathrm{C} 6\left(39-40^{\circ} \mathrm{C}\right)$ and pure $\mathrm{HTf}_{2} \mathrm{~N}\left(52-56^{\circ} \mathrm{C}\right)$, neither
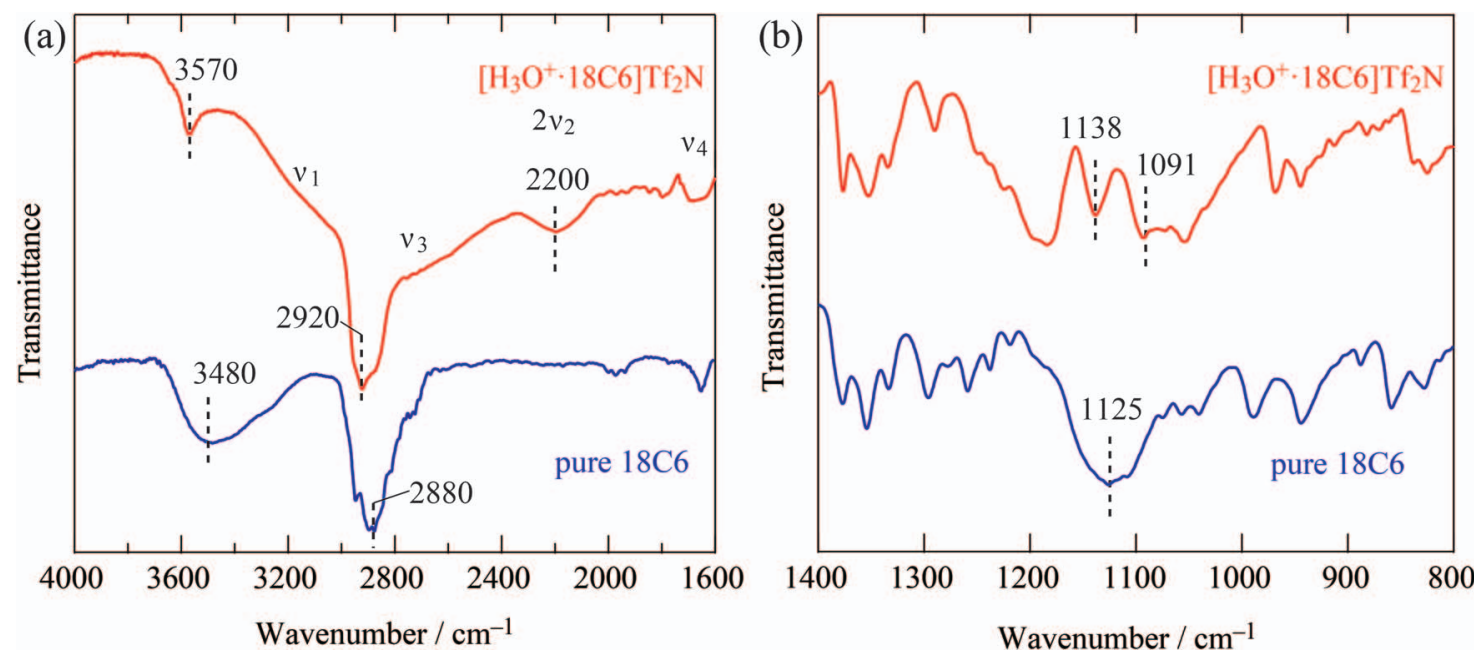

Figure 3. IR spectra of $\left[\mathrm{H}_{3} \mathrm{O}^{+} \cdot 18 \mathrm{C} 6\right] \mathrm{Tf}_{2} \mathrm{~N}$ and pure 18C6: (a) high-wavenumber region from $1600 \mathrm{~cm}^{-1}$ to $4000 \mathrm{~cm}^{-1}$ and (b) low-wavenumber region from $800 \mathrm{~cm}^{-1}$ to $1600 \mathrm{~cm}^{-1}$. 

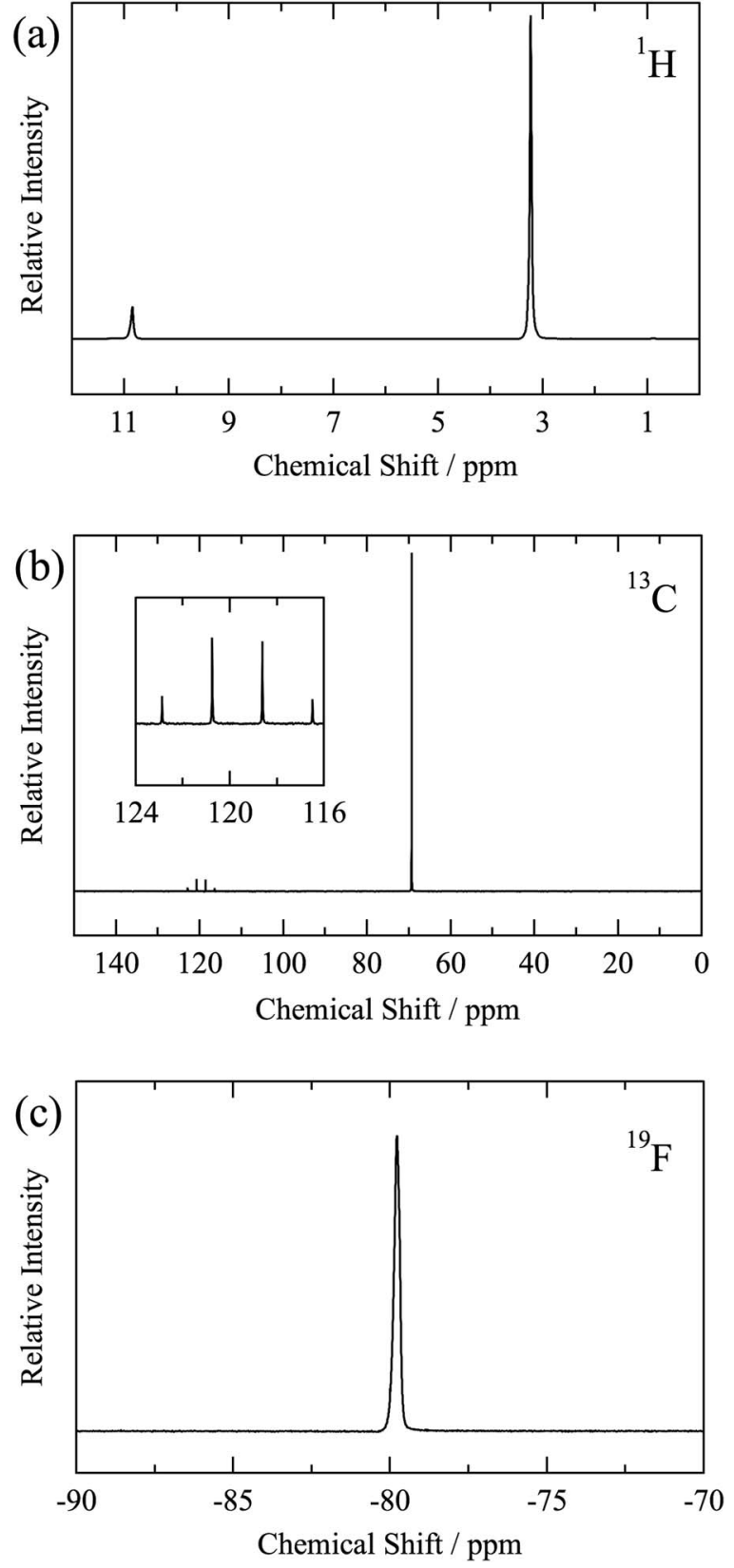

Figure 4. (a) ${ }^{1} \mathrm{H}$ NMR, (b) ${ }^{13} \mathrm{C}$ NMR, and (c) ${ }^{19} \mathrm{~F}$ NMR spectra of $\left[\mathrm{H}_{3} \mathrm{O}^{+} \cdot 18 \mathrm{C} 6\right] \mathrm{Tf}_{2} \mathrm{~N}$ at $75^{\circ} \mathrm{C}$.

free ligands nor precursor $\operatorname{HTf}_{2} \mathrm{~N}$ were included in the sample. This satisfies criterion (3).

Fourthly, the ${ }^{1} \mathrm{H}$ NMR spectra for the molten state $\left(75^{\circ} \mathrm{C}\right.$, Fig. $\left.5 \mathrm{a}\right)$ show only two singlets at $10.85 \mathrm{ppm}$ and $3.23 \mathrm{ppm}$. The former is for $\mathrm{H}_{3} \mathrm{O}^{+}$and the latter is for $\mathrm{CH}_{2}$ of $18 \mathrm{C} 6$. The peak area ratio was $1: 8$, in good agreement with the theoretical ${ }^{1} \mathrm{H}$ ratio for $\mathrm{H}_{3} \mathrm{O}^{+}$and $18 \mathrm{C} 6$, i.e. $\mathrm{C}_{12} \mathrm{H}_{24} \mathrm{O}_{6}$. These chemical shifts agree with those for $\left[\mathrm{H}_{3} \mathrm{O}^{+} \cdot 18 \mathrm{C} 6\right]$ salts dissolved in an organic solvent. ${ }^{32}{ }^{13} \mathrm{C}$ NMR (shown in Fig. 5 b) also revealed the presence of $18 \mathrm{C} 6$ ligands and $\mathrm{Tf}_{2} \mathrm{~N}^{-}$anions with an equimolar ratio: a singlet for $18 \mathrm{C} 6$ at $69.37 \mathrm{ppm}$ and a quartet for $\mathrm{CF}_{3}$ of $\mathrm{Tf}_{2} \mathrm{~N}^{-}$(122.89 ppm, $\left.120.76 \mathrm{ppm}, 118.62 \mathrm{ppm}, 116.50 \mathrm{ppm}\right)$ with a peak area ratio of $6: 1$, which agrees the theoretical ${ }^{13} \mathrm{C}$ ratio 18C6: $\mathrm{Tf}_{2} \mathrm{~N}^{-}=\mathrm{C}_{12} \mathrm{H}_{24} \mathrm{O}_{6}: \mathrm{N}\left(\mathrm{SO}_{2} \mathrm{CF}_{3}\right)_{2}=12: 2$. In comparison, the NMR results for pure $18 \mathrm{C} 6$ at molten state $\left(60^{\circ} \mathrm{C}\right)$ showed a distinguishable change in chemical shift (3.26 ppm for $\mathrm{H}, 70.43 \mathrm{ppm}$ for C; not shown). Fig. 5c displays ${ }^{19}$ F NMR which exhibits a singlet at

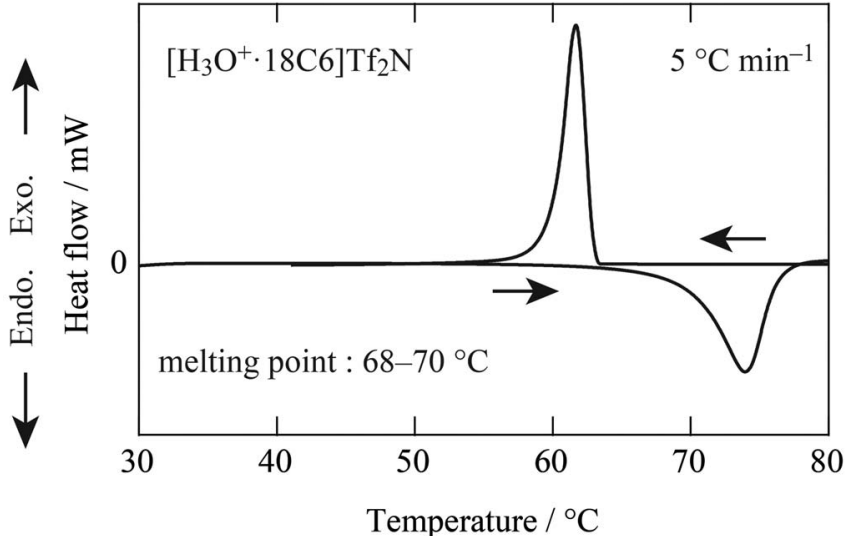

Figure 5. DSC curves for $\left[\mathrm{H}_{3} \mathrm{O}^{+} \cdot 18 \mathrm{C} 6\right] \mathrm{Tf}_{2} \mathrm{~N}$.

$-79.79 \mathrm{ppm}$, the region characteristic of ionic $\mathrm{CF}_{3} \mathrm{SO}_{2}$ derivatives: they fall between $-71 \mathrm{ppm}$ and $-80 \mathrm{ppm}\left(\mathrm{CFCl}_{3}\right)$, shifting to a higher field as the charge on the $\mathrm{CF}_{3} \mathrm{SO}_{2}$ group increases. ${ }^{37}$ Consequently, the $\left[\mathrm{H}_{3} \mathrm{O}^{+} \cdot 18 \mathrm{C} 6\right]$ complex is the only component cation and $\mathrm{Tf}_{2} \mathrm{~N}^{-}$is the only component anion in molten $\left[\mathrm{H}_{3} \mathrm{O}^{+} \cdot 18 \mathrm{C} 6\right] \mathrm{Tf}_{2} \mathrm{~N}$. These NMR results satisfy criteria (1)-(4).

Finally, in the TGA data obtained at $5 \mathrm{~K} \mathrm{~min}^{-1}$ no mass loss was detected below $100^{\circ} \mathrm{C}$ (see Fig. 6). This indicates that neither free $18 \mathrm{C} 6, \mathrm{H}_{2} \mathrm{O}$ nor precursor $\mathrm{HTf}_{2} \mathrm{~N}$ were included in the sample, satisfying criterion (3). Moreover, a $5 \mathrm{wt} \%$ loss was detected at $132^{\circ} \mathrm{C}$, a temperature $60^{\circ} \mathrm{C}$ higher than its melting point. The TGA results suggest a low vapor pressure of $\left[\mathrm{H}_{3} \mathrm{O}^{+} \cdot 18 \mathrm{C} 6\right] \mathrm{Tf}_{2} \mathrm{~N}$ at around its melting point, that is, $\left[\mathrm{H}_{3} \mathrm{O}^{+} \cdot 18 \mathrm{C} 6\right] \mathrm{Tf}_{2} \mathrm{~N}$ has a limited window of usage, e.g. between $50-75^{\circ} \mathrm{C}$. At such a temperature range, however, the vapor pressure can be negligible, satisfying criterion (5).

In all, criteria (1)-(5) were satisfied to classify $\left[\mathrm{H}_{3} \mathrm{O}^{+} \cdot 18 \mathrm{C} 6\right] \mathrm{Tf}_{2} \mathrm{~N}$ as a solvate IL. The solvate ILs reported so far are binary mixtures of alkali-metal salts and polyethers. ${ }^{7-13}$ In contrast, the hydronium solvate IL, the first example of a nonmetal-cation-solvate IL, is a ternary mixture of water, crown ether, and fluorinated imide superacid. Surveying the analogous compounds would give hydronium solvate ILs that have wide temperature windows of usage.

Conductivity and viscosity of the hydronium solvate IL $\left[\mathrm{H}_{3} \mathrm{O}^{+} . \mathbf{1 8 C 6}\right] \mathrm{Tf}_{2} \mathrm{~N}$. - It is interesting to study the bath properties of molten $\left[\mathrm{H}_{3} \mathrm{O}^{+} \cdot 18 \mathrm{C} 6\right] \mathrm{Tf}_{2} \mathrm{~N}$, since the observed strong acidity implies high proton conduction. Table II lists the conductivities and viscosities at several temperatures. Although the temperature range is narrow, we estimated the activation energy from Arrhenius plots,

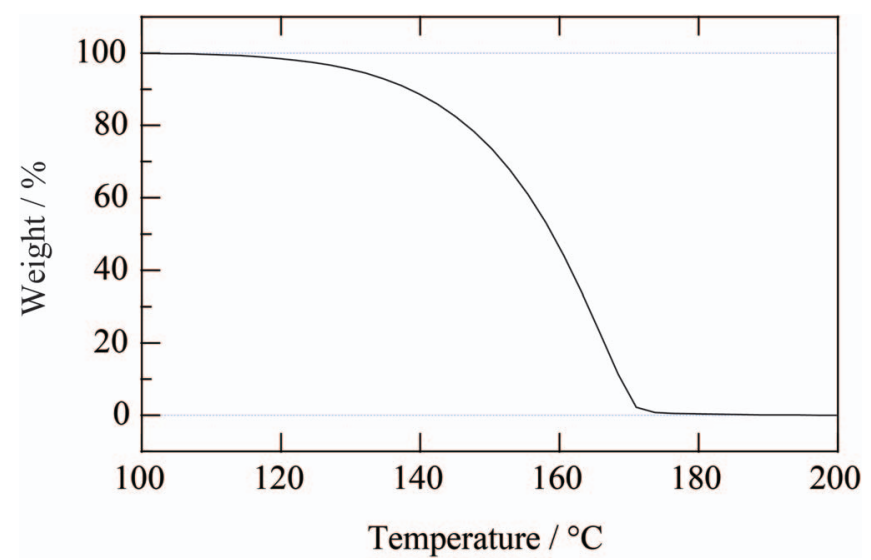

Figure 6. TGA data for $\left[\mathrm{H}_{3} \mathrm{O}^{+} \cdot 18 \mathrm{C} 6\right] \mathrm{Tf}_{2} \mathrm{~N}$ at $5 \mathrm{~K} \mathrm{~min}^{-1}$. 


\begin{tabular}{|c|c|c|}
\hline Temperature $\left[{ }^{\circ} \mathrm{C}\right]$ & Viscosity [mPa s] & Conductivity $\left[\mathrm{mS} \mathrm{cm}^{-1}\right]$ \\
\hline 75 & 42.9 & 2.36 \\
\hline 80 & 37.0 & 2.72 \\
\hline 85 & 32.3 & 3.05 \\
\hline 89 & 29.1 & 3.43 \\
\hline 94 & 25.5 & 3.91 \\
\hline
\end{tabular}

giving comparable values: $28.0 \mathrm{~kJ} \mathrm{~mol}^{-1}$ for ionic conduction and $28.9 \mathrm{~kJ} \mathrm{~mol}^{-1}$ for viscous flow with the correlation coefficients $\mathrm{R}^{2}=0.999$ in both cases. Figure 7 shows a plot of molar conductivity $\left(\Lambda_{\text {imp }}\right.$; measured by AC impedance method) vs. fluidity $\left(\eta^{-1}\right)$, i.e. the Walden plot of $\left[\mathrm{H}_{3} \mathrm{O}^{+} \cdot 18 \mathrm{C} 6\right] \mathrm{Tf}_{2} \mathrm{~N}$. Here $\Lambda_{\text {ideal }}$ is assumed to be the ideal molar conductivity at a given fluidity of an ideal $\mathrm{KCl}$ aqueous solution, where the $\mathrm{K}^{+}$and $\mathrm{Cl}^{-}$ions are completely dissociated and act in an independent fashion. In other words, the absolute value of $\Lambda_{\text {ideal }}\left(\mathrm{S} \mathrm{cm}^{2} \mathrm{~mol}^{-1}\right)$ is equal to that of fluidity, $\eta^{-1}$ (Poise ${ }^{-1}$ or 10 $\mathrm{Pa}^{-1} \mathrm{~s}^{-1}$ ), giving the ideal $\mathrm{KCl}$ line (solid line in Fig. 7). The ionicity i.e. the degree of cation-anion dissociation, is estimated as a conductivity ratio $\Lambda_{\text {imp }} / \Lambda_{\text {ideal }}$ : in the Walden plot the measure of ionicity is the vertical deviation from the ideal line $\Delta W=\log \left(\Lambda_{\text {imp }} / \Lambda_{\text {ideal }}\right) .{ }^{46}$ The value of $\Delta W$ for $\left[\mathrm{H}_{3} \mathrm{O}^{+} \cdot 18 \mathrm{C} 6\right] \mathrm{Tf}_{2} \mathrm{~N}$ is -0.36 , resulting in $\Lambda_{\text {imp }} / \Lambda_{\text {ideal }}$ $=0.44\left(10^{-0.36}=0.44\right)$; this represents the situation where the IL is exhibiting as high as $44 \%$ of the conductivity that might be expected on the basis of its viscosity. Using ionicity, solvate ILs have been categorized as good ILs $(0>\Delta W>-1)$ and poor ILs $(-1>\Delta W):^{7-9,13}$ thus, the hydronium solvate IL is a good IL, and is comparable to common ILs.

We stress that the conductivity of the $\left[\mathrm{H}_{3} \mathrm{O}^{+} \cdot 18 \mathrm{C} 6\right] \mathrm{Tf}_{2} \mathrm{~N}$ sample is not assisted by excess water, which would help proton conduction. The IR spectra clearly show the absence of unprotonated water in the sample. The broad band due to unprotonated water was observed at $3480 \mathrm{~cm}^{-1}$ for pure (as received) $18 \mathrm{C} 6$ (see Fig. 3 ); ${ }^{47}$ the water content was $0.14 \mathrm{wt} \%$ analyzed by Karl-Fischer titration. For the "pure" complex, however, the broad band at $3480 \mathrm{~cm}^{-1}$ due to unprotonated water disappeared, while a sharp band appeared at $3570 \mathrm{~cm}^{-1}$, which may be due to the presence of $\mathrm{H}_{3} \mathrm{O}^{+}$. Notably, when excess water was added to $\left[\mathrm{H}_{3} \mathrm{O}^{+} \cdot 18 \mathrm{C} 6\right] \mathrm{Tf}_{2} \mathrm{~N}$, a broad band appeared at $3200-3600 \mathrm{~cm}^{-1}$ (not shown). Therefore, unprotonated water, which

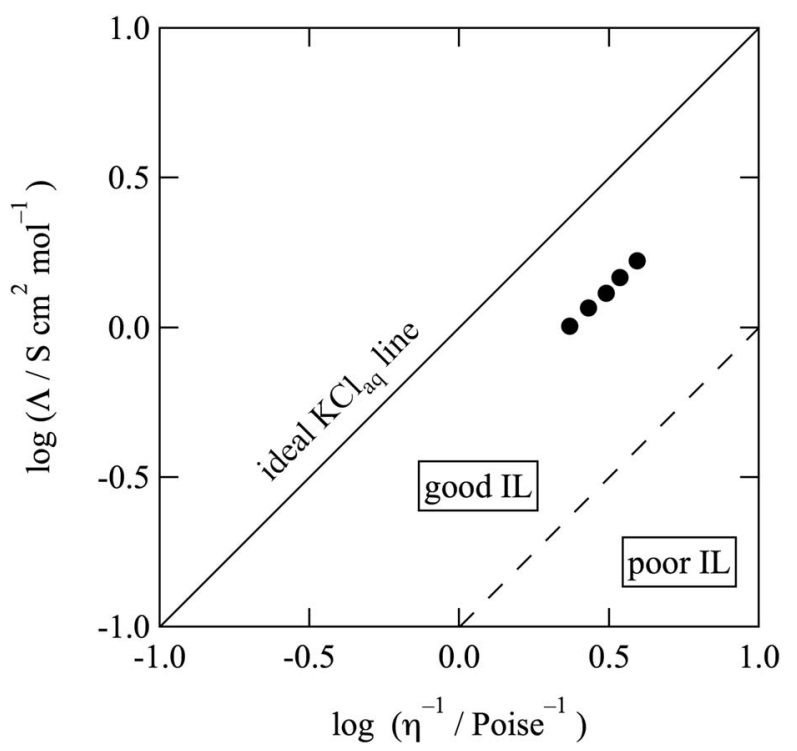

Figure 7. Walden plots for $\left[\mathrm{H}_{3} \mathrm{O}^{+} \cdot 18 \mathrm{C} 6\right] \mathrm{Tf}_{2} \mathrm{~N}$

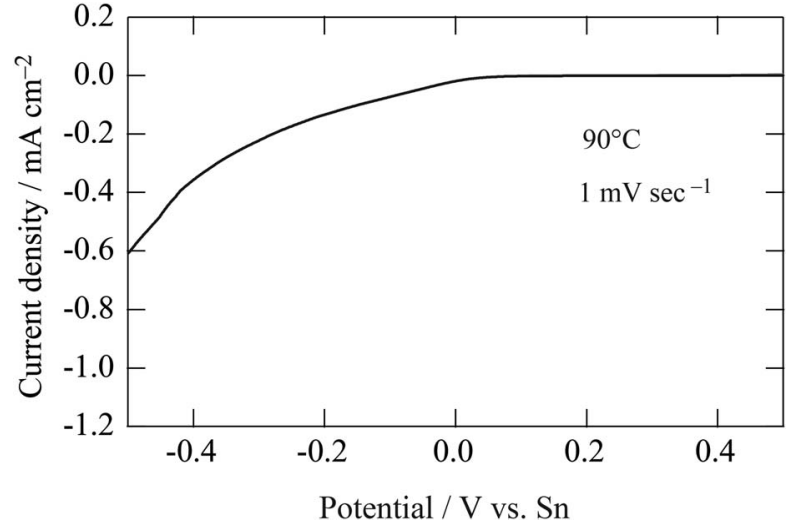

Figure 8. $\mathrm{LSV}$ measured for $\left[\mathrm{H}_{3} \mathrm{O}^{+} \cdot 18 \mathrm{C} 6\right] \mathrm{Tf}_{2} \mathrm{~N}$ with $1 \mathrm{mV} \mathrm{sec}{ }^{-1}$ at $90^{\circ} \mathrm{C}$.

would help proton conduction, is excluded in the $\left[\mathrm{H}_{3} \mathrm{O}^{+} \cdot 18 \mathrm{C} 6\right] \mathrm{Tf}_{2} \mathrm{~N}$ sample, proving that intrinsic conductivity data are obtained.

Acidity of the hydronium solvate $\mathrm{IL}_{[}\left[\mathrm{H}_{3} \mathrm{O}^{+} \cdot 18 \mathrm{C6}\right] \mathrm{Tf}_{2} \mathrm{~N}$.-Figure 8 shows the LSV result for $\left[\mathrm{H}_{3} \mathrm{O}^{+} \cdot 18 \mathrm{C} 6\right] \mathrm{Tf}_{2} \mathrm{~N}$ obtained at $90^{\circ} \mathrm{C}$. An increase in reduction current was observed below approximately $+0.026 \mathrm{~V}$ vs. Sn where the current reached $20 \mu \mathrm{A} \mathrm{cm}^{-2}$. Since the redox potential of $\mathrm{Sn} / \mathrm{Sn}^{2+}$ in aqueous solution is $-0.1375 \mathrm{~V}$ vs. SHE, the observed reduction potential was not far below $0 \mathrm{~V}$ vs. SHE. This strongly suggests high proton activity or high acidic strength of $\left[\mathrm{H}_{3} \mathrm{O}^{+} \cdot 18 \mathrm{C} 6\right] \mathrm{Tf}_{2} \mathrm{~N}$.

The $\mathrm{pH}$ acidity scale cannot be used for ILs because they are nonaqueous. Instead, the Hammett acidity function $H_{0}$ of an IL is evaluated from UV-visible measurements of the IL specimen mixed with an indicator. ${ }^{40-42}$ By this evaluation method, the ILs with the strongest acidities were reported in 2007 and 2009: $H_{0}=-3.6$, both being $\mathrm{SO}_{3} \mathrm{H}$-functionalized ILs. ${ }^{18,19}$ Using the indicator 2,4-dinitroaniline with $\mathrm{p} K_{\mathrm{a}}=-4.53$, the Hammett acidity function $H_{0}$ was determined for $\left[\mathrm{H}_{3} \mathrm{O}^{+} \cdot{ }_{18 \mathrm{C} 6}\right] \mathrm{Tf}_{2} \mathrm{~N}$. In Fig. 9, the UV-vis results showed a decrease in the intensity of the peak centered at $\sim 337.6 \mathrm{~nm}$, indicating that $43 \%$ of the indicator was protonated. The value of $H_{0}$ was -4.4 for $\left[\mathrm{H}_{3} \mathrm{O}^{+} \cdot 18 \mathrm{C} 6\right] \mathrm{Tf}_{2} \mathrm{~N}$ at $75^{\circ} \mathrm{C}$, stronger than the previous record for acidic ILs $\left(H_{0}=-3.6\right){ }^{18,19}$ The strong acidity in $\left[\mathrm{H}_{3} \mathrm{O}^{+} \cdot 18 \mathrm{C} 6\right] \mathrm{Tf}_{2} \mathrm{~N}$ results from a combination of the weak bases $18 \mathrm{C} 6$ and $\mathrm{H}_{2} \mathrm{O}$ and the superacid $\mathrm{HTf}_{2} \mathrm{~N}$. In addition, since the amount of free water is negligible, the leveling effect of water is absent in $\left[\mathrm{H}_{3} \mathrm{O}^{+} \cdot 18 \mathrm{C} 6\right] \mathrm{Tf}_{2} \mathrm{~N}$.

Although $\left[\mathrm{H}_{3} \mathrm{O}^{+} \cdot 18 \mathrm{C} 6\right] \mathrm{Tf}_{2} \mathrm{~N}$ is a solid at RT, it also showed strong acidity when dissolved into a RT IL. Table III lists the value of $H_{0}$ at several concentrations of $\left[\mathrm{H}_{3} \mathrm{O}^{+} \cdot 18 \mathrm{C} 6\right] \mathrm{Tf}_{2} \mathrm{~N}$ in $\mathrm{EMITf}_{2} \mathrm{~N}$ solution. The strongest $H_{0}$ was -4.6 , obtained at $2 \mathrm{~mol} \mathrm{dm}^{-3}$. For comparison, $H_{0}$ of $\mathrm{HTf}_{2} \mathrm{~N}$ in $\mathrm{EMITf}_{2} \mathrm{~N}$ solution was also investigated. Table IV lists

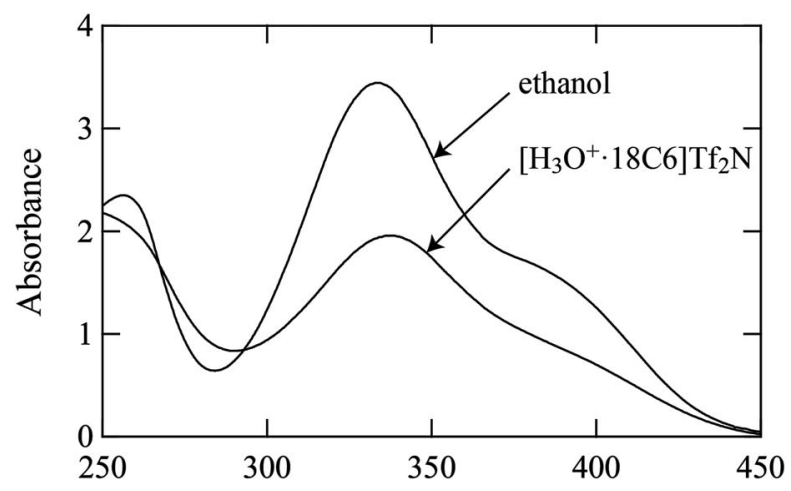

Figure 9. UV-Vis absorption spectra of $2.74 \times 10^{-4} \mathrm{~mol} \mathrm{dm}^{-3} 2,4-$ dinitroaniline in (a) ethanol and (b) $\left[\mathrm{H}_{3} \mathrm{O}^{+} \cdot 18 \mathrm{C} 6\right] \mathrm{Tf}_{2} \mathrm{~N}$ at $75^{\circ} \mathrm{C}$. 


\begin{tabular}{|c|c|c|c|c|}
\hline$\left[\mathrm{H}_{3} \mathrm{O}^{+} \cdot 18 \mathrm{C} 6\right] \mathrm{Tf}_{2} \mathrm{~N}\left[\mathrm{mmol} \mathrm{dm}^{-3}\right]$ & Abs. $\max$ & {$[I][\%]$} & {$\left[I \mathrm{H}^{+}\right][\%]$} & $H_{0}$ \\
\hline 0 & 3.2 & 100 & 0 & - \\
\hline 50 & 2.8 & 88 & 12 & -3.7 \\
\hline 200 & 2.5 & 79 & 21 & -4.0 \\
\hline 400 & 2.2 & 71 & 29 & -4.1 \\
\hline 1000 & 1.8 & 56 & 44 & -4.4 \\
\hline 2000 & 1.4 & 45 & 55 & -4.6 \\
\hline
\end{tabular}

Table IV. Calculation of the Hammett function for EMITf $_{2} N$ solution of $\mathrm{HTf}_{2} \mathbf{N}$.

\begin{tabular}{ccccc}
$\mathrm{HTf}_{2} \mathrm{~N}\left[\mathrm{mmol} \mathrm{dm}^{-3}\right]$ & $\mathrm{Abs} \cdot \max$ & {$[I][\%]$} & {$\left[\mathrm{HH}^{+}\right][\%]$} & $H_{0}$ \\
\hline 0 & 3.2 & 100 & 0 & - \\
50 & 1.6 & 49 & 51 & -4.5 \\
100 & 1.2 & 36 & 64 & -4.8 \\
200 & 0.7 & 22 & 78 & -5.1 \\
400 & 0.5 & 14 & 86 & -5.3 \\
1000 & 0.2 & 6 & 94 & -5.7
\end{tabular}

the values of $H_{0}$ at several concentrations of $\mathrm{HTf}_{2} \mathrm{~N}$ in EMITf $_{2} \mathrm{~N}$ solution, and Fig. 10 displays the $H_{0}$ for $\left[\mathrm{H}_{3} \mathrm{O}^{+} \cdot 18 \mathrm{C} 6\right] \mathrm{Tf}_{2} \mathrm{~N}$-dissolved and $\mathrm{HTf}_{2} \mathrm{~N}$-dissolved EMITf $\mathrm{N}_{2} \mathrm{~N}$ solutions. In both cases, a linear relationship was seen between $H_{0}$ and the logarithm of concentration. Note that similar $H_{0}$ values $\left(-4.5<H_{0}<-5.5\right.$ for $0.5<-\log C$ $<1.0$ ) have been reported for $\mathrm{HTf}_{2} \mathrm{~N}$-dissolved $\mathrm{BMITf}_{2} \mathrm{~N}$ solution $\left(\mathrm{BMI}=1\right.$-butyl-3-methylimidazolium). ${ }^{42}$ Consequently, it was revealed that, in $\mathrm{EMITf}_{2} \mathrm{~N}$ solutions, $\left[\mathrm{H}_{3} \mathrm{O}^{+} \cdot 18 \mathrm{C} 6\right] \mathrm{Tf}_{2} \mathrm{~N}$ is a weaker acid than $\operatorname{HTf}_{2} \mathrm{~N}$, but still a strong acid since the difference in $H_{0}$ is just 1 at the same concentration. Since $\mathrm{HTf}_{2} \mathrm{~N}$ is hygroscopic and sublimes, the air-stable $\left[\mathrm{H}_{3} \mathrm{O}^{+} \cdot 18 \mathrm{C} 6\right] \mathrm{Tf}_{2} \mathrm{~N}$ is advantageous over $\mathrm{HTf}_{2} \mathrm{~N}$ in terms of handling.

\section{Conclusions}

$\left[\mathrm{H}_{3} \mathrm{O}^{+} \cdot 18 \mathrm{C} 6\right] \mathrm{Tf}_{2} \mathrm{~N}$ is the first solvate IL, where nonmetal cations are solvated. This hydronium solvate IL shows strong acidity-due to the absence of the leveling effect of unprotonated water-and a good degree of cation-anion dissociation. The facile synthetic process for $\left[\mathrm{H}_{3} \mathrm{O}^{+} \cdot 18 \mathrm{C} 6\right] \mathrm{Tf}_{2} \mathrm{~N}$ is advantageous over those for other strongly acidic ILs, such as $\mathrm{SO}_{3} \mathrm{H}$-functionalized ILs, which require many laborious steps to obtain the final products. The acidity of hydronium solvate IL can be tuned by using ligands such as thio-crown ethers (more acidic) and aza-crown ethers (more basic). Tailoring the acidity

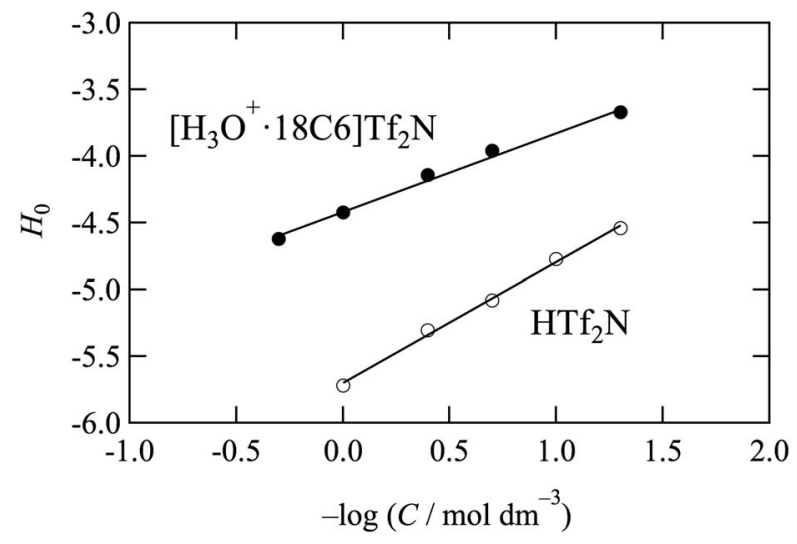

Figure 10. Hammett acidities for $\left[\mathrm{H}_{3} \mathrm{O}^{+} \cdot 18 \mathrm{C} 6\right] \mathrm{Tf}_{2} \mathrm{~N}$ (closed circles) and $\mathrm{HTf}_{2} \mathrm{~N}$ (open circles) dissolved in $\mathrm{EMITf}_{2} \mathrm{~N}$. of ILs via facile synthesis is of special interest for many bio- and electro-chemical applications.

\section{Acknowledgments}

This work was supported financially by Grants-in-Aid for Scientific Research (A) (No. 25249106 and No. 16H02411: K. M.), a Grant-in-Aid for Challenging Exploratory Research (No. 15K14193: K. M.), and a Grant-in-Aid for Young Scientists (B) (No. 15K18253: A. K.) from the Japan Society for the Promotion of Science (JSPS). This work was supported by the Joint Usage/Research Program on Zero-Emission Energy Research, Institute of Advanced Energy, Kyoto University (ZE29A-7). A. K. also thanks Kurita Water and Environment Foundation (No. 16E028), Kyoto University Education and Research Foundation, and FY 2017 Kyoto University Research Development Program ISHIZUE, for their financial supports.

\section{ORCID}

Atsushi Kitada (D) https://orcid.org/0000-0002-4387-8687

\section{References}

1. T. Welton, Chem. Rev., 99, 2071 (1999).

2. K. Fujita, K. Murata, M. Masuda, N. Nakamura, and H. Ohno, RSC Adv., 2, 4018 (2012).

3. T. L. Greaves and C. J. Drummond, Chem. Rev., 115, 11379 (2015).

4. P. A. Hunt, C. R. Ashworth, and R. P. Matthews, Chem. Soc. Rev., 44, 1257 (2015).

5. M. Armand, F. Endres, D. R. MacFarlane, H. Ohno, and B. Scrosati, Nat. Mater, , 8, 621 (2009).

6. A. S. Amarasekara, Chem. Rev., 116, 6133 (2016).

7. T. Mandai, K. Yoshida, K. Ueno, K. Dokko, and M. Watanabe, Phys. Chem. Chem. Phys., 16, 8761 (2014).

8. K. Ueno, K. Yoshida, M. Tsuchiya, N. Tachikawa, K. Dokko, and M. Watanabe, $J$. Phys. Chem. B, 116, 11323 (2012).

9. T. Mandai, S. Tsuzuki, K. Ueno, K. Dokko, and M. Watanabe, Phys. Chem. Chem. Phys., 17, 2838 (2015)

10. Y. Song, H. Jing, B. Li, and D. Bai, Chem. Eur. J., 17, 8731 (2011)

11. A. J. Pawlak and M. L. Dietz, Sep. Sci. Technol., 49, 2847 (2014).

12. Y. Song, C. Cheng, and H. Jing, Chem. Eur. J., 20, 12894 (2014).

13. A. Kitada, D. Ishikawa, K. Fukami, and K. Murase, J. Electrochem. Soc., 164, H5119 (2017).

14. A. R. Hajipour and F. Rafiee, Org. Prep. Proced. Int., 42, 285 (2010).

15. C. Chiappe and S. Rajamani, Eur. J. Org. Chem., 2011, 5517 (2011).

16. R. Skoda-Földes, Molecules, 19, 8840 (2014).

17. Z. Duan, Y. Gu, J. Zhang, L. Zhu, and Y. Deng, J. Mol. Catal. A: Chem., 250, 163 (2006).

18. Y. L. Geng, L. Y. Hu, X. Q. Zhao, H. L. An, and Y. J. Wang, Chin. J. Chem. Eng., 17, $756(2009)$.

19. H. Xing, T. Wang, Z. Zhou, and Y. Dai, J. Mol. Catal. A: Chem., 264, 53 (2007).

20. C. A. Reed, Acc. Chem. Res., 46, 2567 (2013).

21. C. I. Ratcliffe and D. E. Irish, in Water Science Reviews, Vol. 3 (Ed: F. Franks,), Cambridge University Press, Cambridge, UK, 149 (1988).

22. M. Volmer, Justus Liebigs Ann. Chem.: Eur. J. Org. Chem., 440, 200 (1924)

23. M. S. Miran, T. Yasuda, R. Tatara, M. A. B. H. Susan, and M. Watanabe, Faraday Discuss., 206, 353 (2018).

24. A. A. Rahman, A. Usman, S. Chantrapromma, and H.-K. Fun, Acta. Crystallogr. C, 59, i92 (2003).

25. A. Haas, Ch. Klare, P. Betz, J. Bruckmann, C. Krüger, Y.-H. Tsay, and F. Aubke, Inorg. Chem., 35(7), 1918 (1996).

26. E. S. Stoyanov, K.-C. Kim, and C. A. Reed, J. Phys. Chem. A, 108, 9310 (2004).

27. J. K. Clark, S. J. Paddison, M. Eikerling, M. Dupuis, and T. A. Zawodzinski Jr., J. Phys. Chem. A, 116, 1801 (2012).

28. R. Attig and D. Mootz, Acta Crystallogr., B31, 1212 (1975).

29. P. C. Junk, New J. Chem., 32, 762 (2008).

30. G. S. Heo and R. A. Bartsch, J. Org. Chem., 47, 3557 (1982).

31. R. Chénevert, A. Rodrigue, P. Beauchesne, and R. Savoie, Can. J. Chem., 62, 2293 (1984).

32. R. Chenevert and A. J. Rodrique, Chem. Educ., 61, 465 (1984).

33. R. Chênevert, D. Chamberland, M. Simard, and F. Brisse, Can. J. Chem., 67, 32 (1989).

34. P. Bonhôte, A.-P. Dias, M. Armand, N. Papageorgiou, K. Kalyanasundaram, and M. Grätzel, Inorg. Chem., 35, 1168 (1996).

35. H. Kato, K. Miki, T. Mukai, K. Nishikawa, and Y. Koga, J. Phys. Chem. B, 113, 14754 (2009). 
36. G. J. Wilson, A. F. Hollenkamp, and A. G. Pandolfo, Chemistry International, 29(4), July-August 2007: Resolving Ambiguous Naming for an Ionic Liquid Anion: https://www.iupac.org/publications/ci/2007/2904/ud.html\#one

37. J. Foropoulos Jr. and D. D. DesMarteau, Inorg. Chem., 23, 3720 (1984).

38. G. J. Leigh, H. Favre, and W. V. Metanomski, Principles of Chemical Nomenclature: A Guide to IUPAC Recommendations, ed. G.J. Leigh, Blackwell Science, 1998.

39. K. Murase, A. Ito, T. Ichii, and H. Sugimura, J. Electrochem. Soc., 158, D335 (2011).

40. C. Thomazeau, H. Olivier-Bourbigou, L. Magna, S. Luts, and B. Gilbert, J. Am. Chem. Soc., 125, 5264 (2003)
41. S. K. Shukla and A. Kumar, Chem. Phys. Lett, 566, 12 (2013).

42. T. Robert, L. Magna, H. Olivier-Bourbigou, and B. Gilbert, J. Electrochem. Soc., 156, F115 (2009)

43. R. P. Swatloski, J. D. Holbrey, and R. D. Rogers, Green Chem., 5, 361 (2003).

44. A. Kitada, Y. Kang, K. Matsumoto, K. Fukami, R. Hagiwara, and K. Murase, J. Electrochem. Soc., 162(8), D389 (2015).

45. K. T. Munson, J. Vergara, L. Yu, and T. D. Vaden, J. Phys. Chem. B, 119, 6304 (2015).

46. C. A. Angell, Y. Ansari, and Z. Zhao, Faraday Discuss., 154, 9 (2012).

47. B. I. El-Eswed, M. B. Zughul, and G. A. W. Derwish, J. Incl. Phenom., 28, 245 (1997). 